\title{
Establishment and characterisation of a new cell line derived from Culex quinquefasciatus (Diptera: Culicidae)
}

\author{
Nidya A Segura ${ }^{1 /}{ }^{+}$, Erika Santamaría ${ }^{2}$, Olga L Cabrera ${ }^{2}$, Felio Bello ${ }^{1}$ \\ ${ }^{1}$ Laboratorio de Entomología Médica y Forense, Universidad del Rosario, Calle 63D 24-31, Bogotá, Colombia \\ ${ }^{2}$ Grupo de Entomología, Instituto Nacional de Salud, Bogotá, Colombia
}

\begin{abstract}
Insect cell cultures are an important biotechnological tool for basic and applied studies. The objective of this work was to establish and characterise a new cell line from Culex quinquefasciatus embryonic tissues. Embryonated eggs were taken as a source of tissue to make explants that were seeded in L-15, Grace's, Grace's/L-15, MM/VP12, Schneider's and DMEM culture media with a pH range from 6.7-6.9 and incubated at $28^{\circ} \mathrm{C}$. The morphological, cytogenetic, biochemical and molecular characteristics of the cell cultures were examined by observing the cell shapes, obtaining the karyotypes, using a cellulose-acetate electrophoretic system and performing random amplified polymorphic DNA-polymerase chain reaction analysis, respectively. The Grace's/L-15 medium provided the optimal nutritional conditions for cell adhesion and proliferation. Approximately 40-60 days following the explant procedure, a confluent monolayer was formed. Cellular morphology in the primary cultures and the subcultures was heterogeneous, but in the monolayer the epithelioid morphology type predominated. A karyotype with a diploid number of six chromosomes $(2 n=6)$ was observed. Isoenzymatic and molecular patterns of the mosquito cell cultures matched those obtained from the immature and adult forms of the same species. Eighteen subcultures were generated. These cell cultures potentially constitute a useful tool for use in biomedical applications.
\end{abstract}

Key words: embryonic tissues - culture media - karyotype - isoenzymatic patterns - RAPD-PCR

Culex quinquefasciatus Say, 1823 (Diptera: Culicidae) is an anthropophilic mosquito (Forattini et al. 2000) that has a widespread distribution in tropical and subtropical regions. It is found abundantly in the southern parts of the United States, Central and South America, the tropics of Africa, the Middle and Far East, southern Asia, New Guinea and Australia. The wide distribution of this mosquito both in the northern and southern hemispheres exposes it to a variety of climates and conditions that challenge its survival. On a global level, this species has been associated with the transmission of philaria, as well as Wuchereria bancrofti, Dirofilaria immitis, West Nile virus and other viruses causing Saint Louis encephalitis and Venezuelan equine encephalitis (Rivas et al. 1997, Goddard et al. 2002).

The first arthropod cell line was established from tissues of Antheraea eucalypti moth pupae in Australia by Grace (1962). The study of insect cell cultures has progressed in recent years and more than 500 cell lines from different insect species, mainly corresponding to the Diptera, Lepidoptera, Hemiptera, Homoptera and Orthoptera orders, have been described (Lynn 2001). These cell lines have become an important tool for use in a wide range of studies, including research on intracellular parasites and viral infections, in vitro pathogen

Financial support: Rosario University, NIH (Colombia) + Corresponding author: nidya.segura@urosario.edu.co Received 13 May 2011

Accepted 29 November 2011 propagation, the development of vaccines, pest management, the production of recombinant proteins and molecular studies (Sudeep et al. 2005, Hoshino et al. 2009). In Colombia, Rey et al. (2000), Bello et al. (2001) and Zapata et al. (2005) generated primary cell cultures and cell lines from different species of mosquitoes and sand flies that were capable of continuous growth. These cells were characterised morphologically, cytogenetically, biochemically and/or molecularly and, in some cases, were assessed for susceptibility to infection with arboviruses and parasites.

Mosquito cell lines of importance to public health are considered important tools in basic and applied biomedical studies. Although there are a significant number of cell lines that have been established from different mosquito species, they do not address all of the needs of various basic and applied fields of research where cells are required. In addition, mosquito cell cultures, even when derived from the same species but from different tissues, are not necessarily interchangeable or useful for the same purposes.

Hsu et al. (1970) established a cell line that was derived from the ovarian tissues of $C x$. quinquefasciatus. These cells were characterised morphologically and cytogenetically and showed notable particularities in their pattern of growth and cell shape. In addition, Hsu (1971) studied the susceptibility of the ovarian cells to infection with nine arboviruses and showed that all of the viruses tested, except for Eastern equine encephalitis virus and Sindbis, replicated in $C x$. quinquefasciatus cell cultures to various degrees. The present paper describes, for the first time, the establishment and analysis (morphological, cytogenetic, biochemical and molecular) of a new cell line derived from the embryonic tissues of $C x$. quinquefasciatus. 


\section{MATERIALS AND METHODS}

Obtaining biological material - Embryonated eggs from $C x$. quinquefasciatus were taken from a colony that was maintained in the insectary of the Entomology Group, National Health Institute, in March 2009. The colony was established from adults collected in an urban area of Bogotá located at $4^{\circ} 36^{\prime} 43^{\prime \prime} \mathrm{N}$ and $74^{\circ} 04^{\prime} 07^{\prime \prime} \mathrm{W}$ at 2,600 meters above sea level, which is the geographical centre of Colombia.

Primary culture initiation - For each explant of embryonated tissues, eight-10 rafts, composed of approximately 600 eggs, were placed in a Petri dish. After an incubation period of 12-20 h, the eggs were refrigerated for $24 \mathrm{~h}$ and then incubated at $28^{\circ} \mathrm{C}$ for $6 \mathrm{~h}$ following the protocol of Oelofsen et al. (1990). Subsequently, the eggs were manually separated using a soft bristle paintbrush inside a laminar flow chamber. The eggs were then placed into a $50 \mathrm{~mL}$ centrifuge tube that was previously rinsed with a $95 \%$ solution of ethanol and rinsed two times for $1 \mathrm{~min}$ with the same solution. During this period, the tube was stirred repeatedly. The ethanol solution was then removed, $0.5 \%$ sodium hypochlorite was added and the tube was continuously stirred for $5 \mathrm{~min}$. The eggs were washed three times with sterile distilled water and then rinsed with the growth medium to be used. One millilitre of the egg mass was placed into a $2 \mathrm{~mL}$ Ten Brock homogeniser, where the eggs were disrupted mechanically. The resultant solution was placed in a $25 \mathrm{~cm}^{2}$ plastic tissue culture flask containing $10 \mathrm{~mL}$ of the growth medium. To assess the best culture medium, the seeding of embryonic tissues was carried out separately in the following culture media: L-15 (Gibco), Grace's (Gibco), Grace's/L-15, MM/VP12 (Varma \& Pudney 1969), Schneider's (Sigma) and DMEM (Gibco). All media were supplemented with $20 \%$ foetal bovine serum (FBS) and a mixture of penicillin (100 units $/ \mathrm{mL}$ ), streptomycin (100 units/mL) and antimycotics $(2.5 \mu \mathrm{g} /$ $\mathrm{mL}$ Amphotericin B) and the $\mathrm{pH}$ of the media was adjusted to between 6.7-6.9. The culture flasks, each containing both the selected growth medium and the cells, were incubated at $28^{\circ} \mathrm{C}$ without $\mathrm{CO}_{2}$.

Subcultures - The first successful subculture was obtained in March 2010 and since that time 18 passages have been performed to date. The disruption of the confluent monolayers was done mechanically with the help of a rubber policeman. After the cells were resuspended, they were mixed by vigorous pipetting and the cell solution was transferred to a new flask containing $5 \mathrm{~mL}$ of fresh medium. The first five subcultures were passaged at a ratio of 1:1 for each subculture with an average duration of 30 days between each passage. From the sixth-12th passages, subcultures were carried out in a passage split ratio of 1:1 at 15 day intervals. Thereafter, the split ratio was increased gradually to a 1:3 ratio every eight days.

Morphological characteristics - Cell shapes were determined by daily observation using an inverted microscope with a microphotographic system (Leica DMLI) at 100-400X magnification. The most representative cells were photographed.
Cytogenetic characteristics - Samples of subcultures (passage 15) were used to obtain metaphasic chromosomes. Colchicine $(0.6 \mu \mathrm{g} / \mathrm{mL})$ was added to the cultures for a period of $3 \mathrm{~h}$. The cell suspension was then removed and centrifuged at $800 \mathrm{~g}$ for $10 \mathrm{~min}$. The supernatant was discarded and $0.56 \% \mathrm{KCl}$ was added to the pellet. The mixture was stirred by flushing with a Pasteur pipette and left for $30 \mathrm{~min}$. The mixture was then centrifuged again and Carnoy's fixative (methanol and acetic acid, 3:1) was added for $15 \mathrm{~min}$. After three successive washes with Carnoy's, $1 \mathrm{~mL}$ of the cell suspension was dropped onto clean and degreased slides. The dried preparation was stained with $2 \%$ Giemsa's stain. The best metaphase arrays from the slides were selected and microphotographed.

Analyses of isozyme patterns - The isoenzymatic phenotypes of the following four enzymes were examined: malic dehydrogenase, glucose-6-phosphate dehydrogenase, phosphoglucose isomerase and phosphoglucose mutase. Isoenzymes were separated using electrophoresis on cellulose acetate according to the procedure described by Brown and Knudson (1980). Cell samples were run simultaneously with $C x$. quinquefasciatus larvae and pupae extracts from the same colony. The four isozymatic patterns from the cell cultures were compared with a cell line from Lutzomyia longipalpis (Lulo) (Rey et al. 2000) and two isozymatic patterns were compared with a cell line from Lutzomyia spinicrassa (Zapata et al. 2005). The relative electrophoretic mobility (REM) was calculated using the formula REM $=\mathrm{e} / \mathrm{a} \times 100$, where "e" corresponds to the distance run in $\mathrm{mm}$ for each enzyme in the $C x$. quinquefasciatus sample and "a" corresponds to the distance run in $\mathrm{mm}$ for each enzyme in the Lulo sample. Migration was measured from the edge of the well, where the sample had been applied to the corresponding band's midpoint (Zapata et al. 2005).

Molecular characterisation [random amplified polymorphic DNA (RAPD)-polymerase chain reaction $(P C R)]$ - DNA was extracted from confluent monolayers of the Cx. quinquefasciatus and Lulo cell lines using the method of Landry et al. (1993). DNA was extracted from adults of the species under study following the procedure proposed by Coen et al. (1982).

The PCR technique was standardised to minimise the potential effects of the variable substances in the reaction mixture on the amplification process. The reaction mixture had the following composition: $2.5 \mu \mathrm{L}$ of Buffer A (10 x), $1 \mu \mathrm{L}$ of dNTPs $(10 \mathrm{mM}), 1.25 \mu \mathrm{L}$ of $\mathrm{MgCl}_{2}(50 \mathrm{mM})$, primer $1(10 \mu \mathrm{M}), 0.2 \mu \mathrm{L}$ of Taq DNA polymerase $(1 \mathrm{U} / \mu \mathrm{L}), 5 \mu \mathrm{L}$ of DNA $(10 \mathrm{ng} / \mu \mathrm{L})$ and $14.05 \mu \mathrm{L}$ of nuclease-free water (final volume of $25 \mu \mathrm{L}$ per sample). Four primers, synthesised by Invitro$\mathrm{gen}^{\mathrm{TM}}$, were selected. The sequence for each of the primers was as follows: A2 $=\left(5^{\prime}-\right.$ TGCCGAGCTG-3'), A10 = (5'-ACGGCGTATG-3'), A20 = (5'-GTTGCGATCC-3') and E07 $=\left(5^{\prime}-\right.$ AGATGCAGCC-3'). The reaction mixture was placed in a thermal cycler (MJ Research) and the PCR was run at $94^{\circ} \mathrm{C}$ for 4 min (denaturation step) followed by 45 cycles consisting of $94^{\circ} \mathrm{C}$ for $1 \mathrm{~min}, 36^{\circ} \mathrm{C}$ for $1 \mathrm{~min}$ (annealing step) and $72^{\circ} \mathrm{C}$ for $2 \mathrm{~min}$ (extension 
step) with an additional $5 \mathrm{~min}$ at $72^{\circ} \mathrm{C}$ for the last cycle (Williams et al. 1990, Kawai \& Mitsuhashi 1997).

The reaction products were electrophoresed in a $1.4 \%$ agarose gel at $35 \mathrm{~mA}$ for $120 \mathrm{~min}$. The agarose plate was then stained in $0.5 \mu \mathrm{g} / \mathrm{mL}$ ethidium bromide in TAE buffer $(40 \mathrm{mM}$ Tris, $20 \mathrm{mM}$ acetic acid, $1 \mathrm{mM}$ $\mathrm{Na}_{2}$ EDTA) and photographed under ultraviolet light. Individual bands were scored as present or absent in the amplification profile of each sample (Williams et al. 1990, Stevens \& Wall 1997).

Band patterns were compared using the similarity coefficient $\left(\mathrm{S}_{\mathrm{AB}}\right)$ of Ney and $\mathrm{Li}$ (1979), which is represented by the following formula: $\mathrm{S}_{\mathrm{AB}}=2 \mathrm{~N}_{\mathrm{AB}} /\left(\mathrm{N}_{\mathrm{A}}+\mathrm{N}_{\mathrm{B}}\right)$, where $\mathrm{N}_{\mathrm{A}}$ and $\mathrm{N}_{\mathrm{B}}$ correspond to the total number of bands shown by individual $\mathrm{A}$ and individual $\mathrm{B}$, respectively, and $\mathrm{N}_{\mathrm{AB}}$ is the number of shared bands.

Cryopreservation - Semi-confluent culture monolayers were disrupted and the detached cells were adjusted to $5 \times 10^{6} / \mathrm{mL}$ in freezing medium $(50 \%$ Grace's/L15, $40 \%$ FBS and $10 \%$ dimethyl sulfoxide). The cell suspension was dispensed into sterile cryotubes and refrigerated at $5^{\circ} \mathrm{C}$ for $20 \mathrm{~min}$, then frozen at $-70^{\circ} \mathrm{C}$ overnight prior to permanent storage in liquid nitrogen.

\section{RESULTS}

Primary culture initiation - Obtaining primary cultures from embryonic tissues was successful using Grace's/L15 medium. There was no cell growth in Grace's, L-15, Schneider's, MM, VP12, MM/VP12 or DMEM media. The best results at the initiation of the cell cultures were achieved using eggs that had been incubated for $16-20 \mathrm{~h}$ followed by refrigeration $\left(4^{\circ} \mathrm{C}\right)$ for up to $24 \mathrm{~h}$ and then additionally incubated for $4-6 \mathrm{~h}$ at $28^{\circ} \mathrm{C}$. Cell growth during the primary culture was slow and in the first weeks of adhesion and cell growth some tissue fragments with pulsating movement were observed and continued to be observed in some cases for more than three weeks. The presence of vesicles was also observed (Fig. 1A), many of which were in suspension and some of which adhered to the cells in the monolayer. Observation through an inverted microscope revealed that the vesicles were formed by a monolayer of epithelioid cells surrounding an empty space. With increased time in culture, the vesicles became greatly increased in size and number. After rupturing, these vesicles were an important source of cell release that contributed to cell proliferation in the primary cell culture and hence, to the formation of the confluent monolayer.

A confluent monolayer was achieved after 40-60 days of incubation (Fig. 1B), at which time the cells were growing and adhering firmly to the flask surface. Eighteen serial subcultures were performed and the initial subcultures demonstrated a similar slow growth rate with low cell proliferation as the primary cultures. However, after the sixth passage, cell division increased in the cultures. At this time, the cells were subcultured at a ratio of 1:3 once per week. The viability of frozen cells was shown at five months after freezing.

Morphological characteristics - Cx. quinquefasciatus cell cultures in the initial growth stages showed heterogeneous cell morphology, demonstrating spheri- cal, elongated, irregular and, occasionally, giant shapes. However, the predominant morphological type was the epithelioid type, which was observed in the confluent monolayer (Fig. 2), as well as in the subcultures.

Cytogenetic characteristics - The metaphase arrays obtained from primary cultures and subcultures of $C x$. quinquefasciatus exhibited a diploid chromosomal number $(2 n=6)$ (Fig. 3). The classification of the chromosomes was performed according to the size in ascending order and the position of the centromeres. Thus, pairs 1 and 2 were classified as metacentric, whereas pair 3 was classified as sub-metacentric.
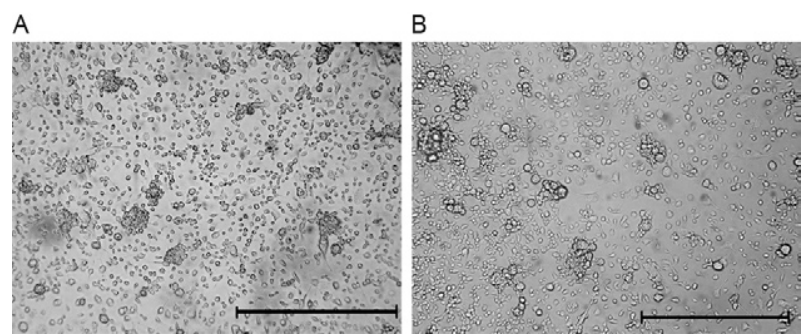

Fig. 1A: vesicles in suspension during the initiation process of the primary cell cultures from embryonic tissues of Culex quinquefasciatus; $\mathrm{B}$ : confluent monolayer $C x$. quinquefasciatus formed at 60 days of embryonic tissues explanted. $\mathrm{Bar}=200 \mu \mathrm{m}$.

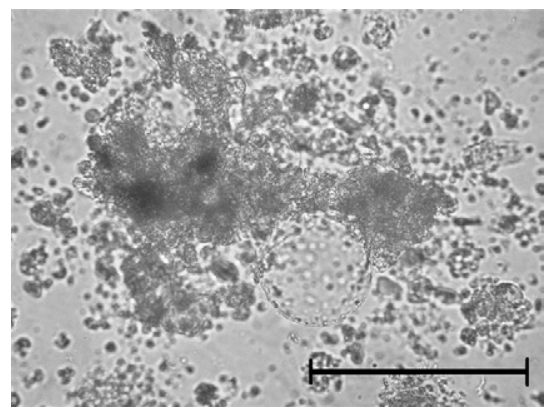

Fig. 2: monolayer of Culex quinquefasciatus cells showing epithelioid cellular morphology (subculture 5). Bar $=200 \mu \mathrm{m}$.

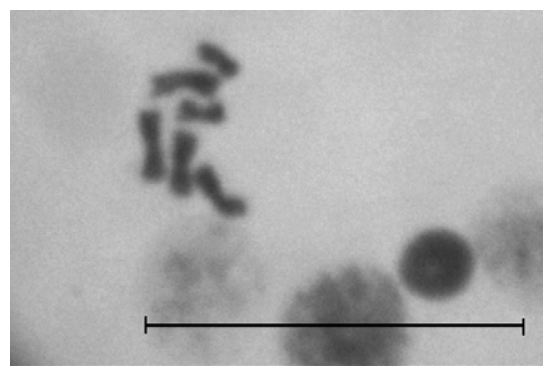

Fig. 3: diploid chromosomes from Culex quinquefasciatus cells in culture. $\operatorname{Bar}=25 \mu \mathrm{m}$. 
Isoenzymatic profiles - The four isoenzymatic systems used to characterise the $C x$. quinquefasciatus cell cultures were used to establish the identity of the new cell line by comparing its isoenzymatic band patterns with those from mosquito larvae and pupae, as band patterns exhibited by the Lulo and Lu. spinicrassa cell lines were different from each other and from the new cell line. The four systems analysed (ME, G-6-PDH, PGI and PGM) showed one band in both the cell line and the Cx. quinquefasciatus larvae and pupae. However, the Lulo cell line also showed a zymogram with one band in each of the isoenzymatic systems evaluated, but with different relative mobility values, whereas the cell line from $\mathrm{Lu}$. spinicrassa was heterozygotic for the PGM system (Table I).

$R A P D-P C R$ analysis - With the A2 primer, seven DNA fragments were recorded for the Lulo cell line and for the cell cultures and adults from $C x$. quinquefasciatus, the number of DNA fragments was 13 (Fig. 4A). With the A10 primer, a profile of 17 DNA fragments was obtained from cell cultures and adults from $C x$. quinquefasciatus, whereas 13 fragments were obtained from the Lulo cell line (Fig. 4B). Using the A20 primer, 11 DNA fragments were obtained from Lulo and six were obtained from the adult mosquito and cell culture samples (Fig. 4C). Finally, with the EO7 primer, the results showed eight DNA fragments for the $C x$. quinquefasciatus species (cell cultures and adults), nine for the $L u$. spinicrassa cell line and six for the Lulo cell line (Fig. 4D). Generally, the DNA fragments obtained covered a range from $300-1,100 \mathrm{bp}$.

The $\mathrm{S}_{\mathrm{AB}}$ values between DNA bands of the cell cultures and adults of $C x$. quinquefasciatus were identical. In contrast, the values obtained from $C x$. quinquefasciatus and the Lulo cell line and, in one case (primer E07), from the $L u$. spinicrassa cell line, were all different (Table II).

\section{DISCUSSION}

One of the important variables in the initiation of cell cultures is the timing of egg embryogenesis used in the tissue explants. In the present study, an optimal incubation time of between 16-20 h was determined to achieve successful cell cultures, which corresponds to approximately $2 / 3$ of the total time of embryo formation before the egg hatches. A similar finding has been published in previous studies on the establishment of cell lines derived from mosquitoes (Pant \& Dandha 1980, Bello et al. 1997). In addition to the above-mentioned incubation period, the embryonated eggs that produced the best results at the initiation of the cell cultures were those that received an additional $4-6 \mathrm{~h}$ of incubation at $28^{\circ} \mathrm{C}$. It was also observed that the eggs retained their viability for up to $24 \mathrm{~h}$ when they were refrigerated at $4^{\circ} \mathrm{C}$ and after leaving them at room temperature for $30 \mathrm{~min}$ and then incubating them under the additional conditions previously indicated, the eggs produced even better results in establishing the primary cell cultures. Similar results using this same technique were reported by Oelofsen et al. (1990), who suggested that it was possibly the temperature changes that stimulated cell division.

Cell growth in the primary cell cultures until the formation of the confluent monolayer was relatively slow, which is in agreement with previous studies (Rey et al. 2000, Bello et al. 2001, Sudeep et al. 2009). The pattern of cell division and growth depended initially on the embryonic tissue fragments that adhered firmly to the flask surface $12 \mathrm{~h}$ after explantation and, at later times, the cells began to migrate and proliferate from these tissues.

Additionally, during the initial culturing stages, the pulsating movement of the cell cultures suggested the activity of muscle tissue, which is dependent on contractile proteins. Fibre connections could also be observed originating from several fragments, which is perhaps why the
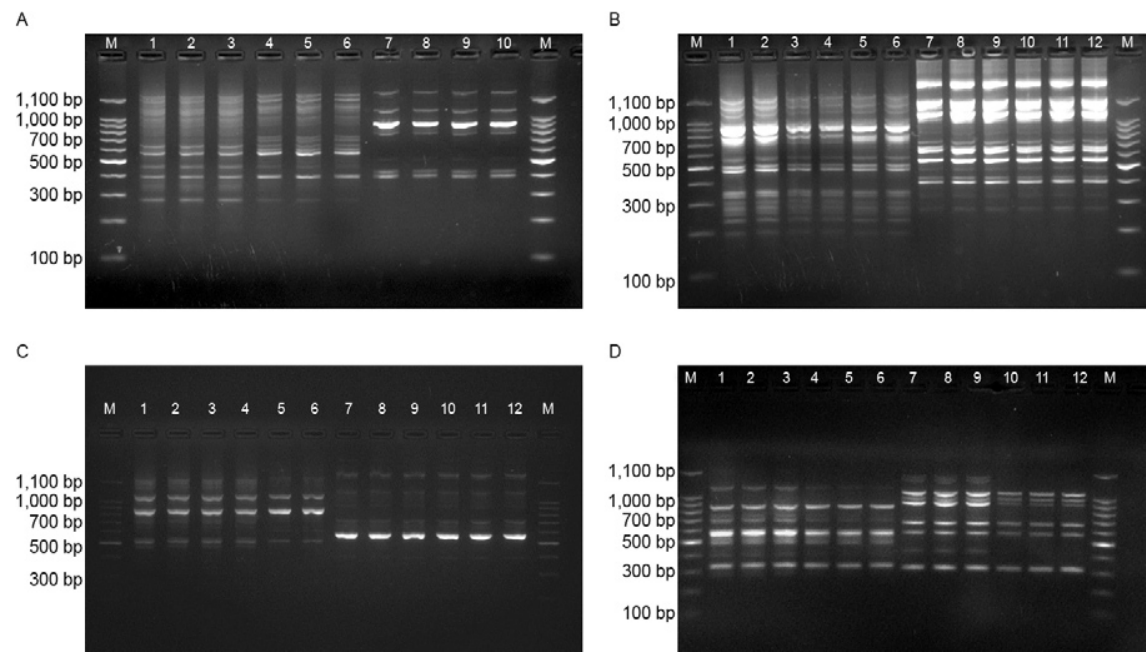

D

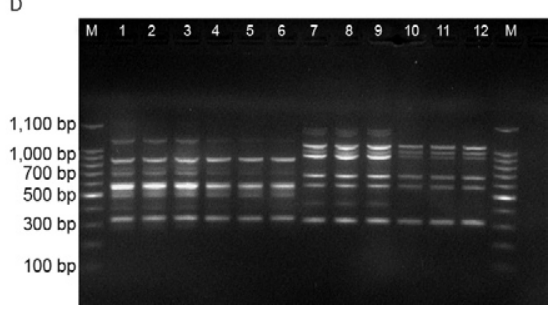

Fig. 4: random amplified polymorphic DNA (RAPD) profiles of the cell line from Culex quinquefasciatus (A) compared with RAPD profiles from Cx. quinquefasciatus adults (B), from Lutzomyia longipalpis cell line (C), from Lutzomyia spinicrassa cell line (D) using four different primers. A2 [Lines 1-3 (A); 4-6 (B); 7-10 (C)]; A10 [1-3 (A); 4-6 (B); 7-12 (C)]; A20 [1-3 (A); 4-6 (B); 7-12 (C)]; EO7 [1-3 (A); 4-6 (B); 7-9 (D); 10-12 (C)]. M: molecular weight marker. 
cells were able to extend and cover more area. These results are in line with observations by Hsu et al. (1970) in ovarian cell cultures of $C x$. quinquefasciatus and those by Duce and Usherwood (1986) in cell cultures of Locusta migratoria and Schistocerca gregaria (Orthoptera: Acrididae). Nevertheless, in the present study, actively growing cells later detached from around the fragments to form localised cell colonies that achieved better extension and were therefore better able to proliferate.

Another important characteristic of the cell growth pattern was the occurrence of vesicles surrounded by cells that facilitated the formation of the confluent monolayer. The occurrence of vesicles in the cell cultures of insects and other arthropods is very common and has been demonstrated in several studies (Charpentier et al. 1995, Rey et al. 2000, Silva et al. 2008).

The culture medium in which the cells were able to adapt, grow and proliferate consisted of a mixture of equal parts of Grace's and L-15 media, indicating that this mixture provided the necessary and sufficient components to initiate the primary cell cultures of $C x$. quinquefasciatus. However, the growth of the first five subcultures was slow and they were similar to the primary cultures in their pattern of growth and division, with an interval of 30 days between subcultures. In addition, particles that could possibly represent metabolite byproducts in response to either an excess or a deficiency of certain substances were observed within the cultured cells and in the medium. However, these particles were not observed subsequent to the sixth subculture.
The cell morphology at the initiation of the primary cell cultures was heterogeneous, but an epithelioid morphology became the predominant cell shape later in the confluent cell monolayer and in the subcultures. This result is likely explained by the variety of tissues present in the initial mixed culture that then further divide and develop predominantly into one of the two cell shapes (epithelioid and fibroblastoid) that are commonly observed in insect cells. In this work, the epithelioid type was predominant, which is in agreement with many other studies on the initiation and establishment of mosquito cell cultures (Bello et al. 2001, Athawale et al. 2002, Zapata et al. 2005, Sudeep et al. 2009).

Regarding the karyological analysis, the number of chromosomes observed matched previous reports on other cell lines of the Culicidae family, including species from the Culex genus (Hsu et al. 1970, Charpentier et al. 1995, Athawale et al. 2002, Sudeep et al. 2009). According to Kitzmiller (1976), the number $(2 n=6)$ and morphology of the Culicidae chromosomes are highly conserved among the whole family. Additionally, the absence of polyploidy demonstrates the integrity of this cell line and indicates that there has not been a transformation like that which occurred in a cell line from the neonate larvae of Aedes aegypti, which showed that greater than $75 \%$ of the cells contained a diploid number of chromosomes (Sudeep et al. 2009).

The isoenzymatic profiles of the $C x$. quinquefasciatus cell line matched identically the profiles of the samples from the immature forms of the same species, showing

TABLE I

Relative electrophoretic mobility for the four isoenzymes used in the study

\begin{tabular}{lcccc}
\hline & Lutzomyia longipalpis & Lutzomyia spinicrassa & Culex quinquefasciatus \\
\cline { 2 - 5 } Systems & Cells & Cells & Larvae Pupa Cells \\
\hline Malic dehydrogenase & 100 & - & 111 & 111 \\
Glucose-6-phosphate dehydrogenase & 100 & - & 111 \\
Phosphoglucose isomerase & 100 & 133 & 108 & 108 \\
Phosphoglucose mutase & 100 & 102.5 & 166 & 166 \\
\hline
\end{tabular}

TABLE II

Similarity coefficients for random amplified polymorphic DNA-polymerase chain reaction profiles using four different primers

\begin{tabular}{lccc} 
& $\begin{array}{c}\text { Culex quinquefasciatus cell line } \\
\text { vs. }\end{array}$ & $\begin{array}{c}\text { C. quinquefasciatus cell line } \\
\text { vs. }\end{array}$ & $\begin{array}{c}\text { C. quinquefasciatus cell line } \\
\text { vs. }\end{array}$ \\
Primer & C. quinquefasciatus adults & Lutzomyia longipalpis cell line & Lutzomyia spinicrassa cell line \\
\hline A2 & 1 & 0.3 & - \\
A10 & 1 & 0.2 & - \\
A20 & 1 & 0.35 & 0.35 \\
E07 & 1 & 0.28 & - \\
\hline
\end{tabular}


in all cases the same mobility patterns, which is indicative of a common origin. In contrast, a comparison of the isoenzymatic profiles of the four systems evaluated with the profiles obtained from the Lulo and Lu. spinicrassa cell lines revealed large differences, indicating diverse origins and ruling out cross contamination among the cell lines used in our laboratory. This methodology has commonly been used to characterise and authenticate different cell lines from insects (Rey et al. 2000, Lynn \& Ferkovich 2004, Zapata et al. 2005, Hoshino et al. 2009).

The identity of the new cell line was also determined using RAPD profiles. Differences were not observed between the $C x$. quinquefasciatus cell line and the adult samples using the four primers described above, thereby confirming the identity of the cell line as being derived from $C x$. quinquefasciatus. This result suggests that the cultured cells did not incur losses of genetic material since they had been established and that their molecular composition, according to the markers assessed, reflected the low allelic diversity of the colonised $C x$. quinquefasciatus strain (Léry et al. 2003). In contrast, when comparing the RAPD profiles of the new cell line with the Lulo cell line and the line derived from $L u$. spinicrassa, a $\mathrm{S}_{\mathrm{AB}}$ lower than 0.3 was shown, corresponding to homology of some bands ( 2 in most cases) and indicating that the cell lines came from different insect species. The four primers used were able to differentiate and confirm the identity of the original sources of the lines from $C x$. quinquefasciatus, Lu. longipalpis and Lu. spinicrassa, as well as determine that there was no cross contamination. The efficiency of this technique has been previously reported and it has been shown to differentiate related species, but the technique has not been used to identify clones of cell lines. In studies using Lu. longipalpis and Lu. spinicrassa, the E07 primer was able to differentiate between two species of the same genus, therefore making it an effective tool to authenticate cell lines that are taxonomically close (McIntosh et al. 1996, Kawai \& Mitsuhash 1997).

A new cell line derived from the embryonic tissues of $C x$. quinquefasciatus was generated and characterised in this study. This cell line will be tested in future studies to assess its usefulness in drug development against arbovirus infections and to identify the molecular mechanism of action of such inhibitors. In addition, it is important to have a larger panel of mosquito cell lines, as they serve as efficient tools to advance studies in multiple areas of biology and biomedicine, including immunology, endocrinology, toxicology, biochemistry, parasitology and evolutionary biology.

\section{ACKNOWLEDGEMENTS}

To Marco Fidel Suarez, for collecting the adults that began the colony of $C x$. quinquefasciatus.

\section{REFERENCES}

Athawale SS, Sudeep AB, Barde PV, Jadi R, Mishra AC, Mourya D 2002. A new cell line from the embryonic tissues of Culex tritaeniorhynchus and its susceptibility to certain flaviviruses. Acta virologica 46: 237-240.

Bello FJ, Brochero H, Boshell J, Olano V, Rey G 1997. Establishment and characterization of a cell line from mosquito Anopheles albimanus (Diptera: Culicidae). Mem Inst Oswaldo Cruz 92: 123-128.
Bello FJ, Rodríguez JA, Escovar J, Olano VA, Morales A, González M, Rey G 2001. A new continuous cell line from the mosquito Psorophora confinnis (Diptera: Culicidae) and its susceptibility to infections with some arboviruses. Mem Inst Oswaldo Cruz 96: 865-873.

Brown JE, Knudson DK 1980. Characterization of invertebrate cells lines. III. Isozyme analyses employing cellulose-acetate electrophoresis. In vitro 14: 255-260.

Charpentier G, Belloncik S, Ducros G, Fontenille D, Tian L, Quiot M 1995. Establishment and characterization of three cell lines from Aedes triseriatus (Diptera: Culicidae). J Med Entomol 32: 793-800.

Coen JE, Strachan T, Dover G 1982. Dynamics of concerted evolution of ribosomal DNA and histone gene families in the Melanogaster species subgroup of Drosophila. J Molec Biol 158: 17-35.

Duce JA, Usherwood PN 1986. Primary cultures of muscle from embryonic locusta (Locusta migratoria, Schistocerca gregaria): developmental, electrophysiological and patch-clams studies. $J$ Exp Biol 12: 307-323.

Forattini O, Kakitani I, La Corte Dos Santos R, Kobayashi K, Ueno H, Fernández Z 2000. Potencial sinantrópico de mosquitos Kertesia e Culex (Diptera: Culicidae) no sudeste do Brasil. Rev Saude Publica 34: 565-569.

Goddard LB, Roth AR, Reisen WK, Scott TW 2002. Vector competence of California mosquitoes for West Nile virus. Em Infect Dis 8: 1385-1391.

Grace TDC 1962. Establishment of four strains of cells from insect tissues grown in vitro. Nature 195: 788-789.

Hoshino K, Hirose M, Iwabuchi K 2009. A new insect cell line from the longicorn beetle Plagionotus christophi (Coleoptera: Cerambycidae). In Vitro Cell Dev Biol Anim 45: 19-22.

Hsu 1971. Growth of arboviruses in arthropod cell cultures: comparative studies. I. Preliminary observations on growth of arboviruses in a newly established line of mosquito cell (Culex quinquefasciatus). Curr Top Microbiol Immunol 55: 140-148.

Hsu SH, Mao WH, Cross JH 1970. Establishment of a line of cells derived from ovarian tissue of Culex quinquefasciatus Say. J Med Entomol 7: 703-707.

Kawai Y, Mitsuhashi J 1997. An insect cell line discrimination method by RAPD-PCR. In Vitro Cell Dev Biol Anim 33: 512-515.

Kitzmiller JB 1976. Genetics, cytogenetics and evolution of mosquitoes. Adv Genet 18: 416-433.

Landry BS, Dextraze L, Boivin G 1993. Random amplified polymorphic DNA markers for DNA fingerprinting and genetic variability assessment of minute parasitic wasp species (Hymenoptera: Mymariadae and Trichogrammatidae) used in biological control programs of phytophagous insects. Genome 36: 580-587.

Léry X, LaRue B, Cossette J, Charpentier G 2003. Characterization and authentication of insect cell lines using RAPD markers. Insect Biochem Mol Biol 33: 1035-1041.

Lynn D 2001. Novel techniques to establish new insect cell lines. In vitro Cell Dev Biol Animal 37: 319-321.

Lynn DE, Ferkovich FM 2004. New cell lines from Ephestia kuehniella: characterization and susceptibility to baculoviruses. J Insect Sci 4: 9.

McIntosh AH, Grasela JJ, Matteri RL 1996. Identification of insect cell lines by DNA amplication fingerprinting (DAF). Insect Mol Biol 5: 187-195.

Ney M, Li W 1979. Mathematical model for studying genetic variation in terms of restriction endonucleases. Proc Natl Acad Sci USA 76: 5269-5273. 
Oelofsen M, Gericke A, Smith M, Van der Linde TC 1990. Establishment and characterization of a cell line from the mosquito Culex (Culex) theileri (Diptera: Culicidae) and its susceptibility to infection with arboviruses. J Med Entomol 27: 939-944.

Pant U, Dandha V 1980. Establishment of a cell line from Culex bitaeniorhynchus. J Tissue Cult Methods 6: 61-63.

Rey GJ, Ferro C, Bello FJ 2000. Establishment and characterization of a new continuous cell line from Lutzomyia longipalpis (Diptera: Psychodidae) and its susceptibility to infections with arboviruses and Leishmania chagasi. Mem Inst Oswaldo Cruz 95: $103-110$

Rivas F, Diaz L, Cárdenas V, Daza E, Bruzón L, Alcalá A, De la Hoz O, Caceres FM, Aristizabal G, Martinez JW, Revelo D, De la Hoz F, Boshell J, Camacho T, Calderon L, Olano VA, Villarreal LI, Roselli D, Alvarez G, Ludwig G, Tsai T 1997. Epidemic Venezuelan equine encephalitis in La Guajira, Colombia 1995. J Infect Dis 175: 828-832.

Silva LM, Lages CP, Venuto T, Lima RM, Diniz MV, Valentim CL, Baba EH, Pimenta PF, Fortes-Dias CL 2008. Primary culture of venom glands from the Brazilian armed spider, Phoneutria nigriventer (Araneae, Ctenidae). Toxicon 51: 428-434.
Stevens J, Wall R 1997. Genetic variation in populations of the Blowflies Lucilia cuprina and Lucilia sericata (Diptera: Calliphoridae). Random amplified polymorphic ADN analysis and mitochondrial ADN sequences. Biochem Syst Ecol 25: 81-97.

Sudeep AB, Mourya DT, Mishra AC 2005. Insect cell culture in research: Indian scenario. Indian J Med Res 121: 725-738.

Sudeep AB, Parashar D, Jadi R, Basu A, Mokashi C, Arankalle V, Mishra A 2009. Establishment and characterization of a new Aedes aegypti (L.) (Diptera: Culicidae) cell line with special emphasis on virus susceptibility. In vitro Cell Dev Biol Animal 45: 491-495.

Varma MGR, Pudney M 1969. The growth and serial passage of cell lines from Aedes aegypti (L) larvae in different media. J Med Entomol 6: 432-439.

Williams JG, Kubelik AR, Livak KJ, Rafalski JA, Tingey SV 1990. DNA polymorphisms amplified by arbitrary primers are useful as genetic markers. Nucleic Acids Res 18: 6531-6535.

Zapata AC, Cárdenas E, Bello F 2005. Characterization of cell cultures derived from Lutzomyia spinicrassa (Diptera: Psychodidae) and their susceptibility to infection with Leishmania (Viannia) braziliensis. Med Sci Monit 11: 457-464. 